\title{
A SURVEY OF FOREST FIRE CAUSES AND SUGGESTED CORRECTIVE MEASURES
}

\author{
BY J. A. DOYLE 1
}

\section{INTRODUCTION}

At the 1950 annual meeting of the Sub-Committee on Forest Fire Research of the Associate Committee on Forestry, National Research Council, a panel was appointed to determine the most effective methods of developing forest fire prevention activities. This panel included representatives of provincial and federal forest fire protection agencies, and forest industry. It was decided that the first step should be to obtain as much information as possible regarding the relative importance of different firestarting agencies and of the immediate causes of fires, from those directly concerned with fire control.

The present classifications of forest fire causes used for statistical purposes in Canada do not provide a satisfactory basis for obtaining such information, inasmuch as they fail to differentiate the specific cause or ignition source from the general cause or type of agency responsible for fire. For instance, in the case of fires attributed to industrial operations, it is impossible to tell whether the majority of the fires resulted from careless smoking habits of employees, from industrial machinery, or from the burning of slash. In many cases the classes are not mutually exclusive, with the result that there may be a choice of classes to which a given fire can properly be assigned. This in turn makes it impossible to determine clearly from the statistics the agency responsible, as a basis for preventive action.

Accordingly, a questionnaire was drafted by the panel and, with the co-operation of various forest protection agencies in Canada, was distributed to district foresters, inspectors, and warden or ranger staffs. It consisted of five questions designed to indicate in order of importance the general and specific causes of fires for particular districts, as well as the three most effective fire prevention methods. In most instances, a wide range of choices was provided, and the reporting officer was requested to check one or more of these choices.

Lightning and railway fires were excluded from the study, as they belong to a special group, and their occurrence and reduction is not a matter of public education.

In Question 1, the reporting officer was asked, (a) whether local citizens cause more fires than tourists, (b) whether white people cause more fires than Indians, and (c) what percentage of the population of the district is Indian.

The second question asked the reporting officers to show in order of

1. Forestry Branch, Department of Resources and Development, Ottawa. 
importance the various classes of people (e.g. settlers, berry-pickers, fishermen) which cause the most fires in their respective districts, and the specific reason (camp fires, smoking, etc.) for most fires started by each of these classes.

Question 3 dealt with settlers' fires and requested that the three most important reasons for such fires be shown, as well as the class of settler responsible for most fires set for each of the three reasons.

Question 4 asked those concerned to indicate in order of importance the three major reasons for incendiary fires.

In Question 5, the reporting officers were asked to select from a list of prevention methods the three methods that they would recommend as being most effective in relation to the classes of people responsible for causing most fires in their districts. Space was provided on the questionnaire for comments by those completing it.

The compiling and summarizing of the replies was done by the Federal Forestry Branch.

The limitations of this subjective approach are realized, but it is nevertheless believed that the results are of considerable value and yield some useful and instructive information regarding the emphasis that should be placed on various phases of forest fire prevention work. It is believed that this is the first attempt that has been made to gather and summarize data of this character.

\section{DISCUSSION}

Three hundred and fifteen replies in all were received from districts located in every province in Canada, as well as the Yukon and the Northwest Territories. However, replies to the questionnaire from districts within the Provinces of British Columbia and Prince Edward Island were received only from the National Parks in those Provinces, while two forest protective associations were the only reporting agencies in the Province of Quebec. In the remaining provinces the information was collected by the forest services therein. Data were also received from most of the National Parks in Canada.

The fact that the results here presented may not coincide with the recorded statistics in certain regions is not necessarily due to defects of the subjective method, which tends to introduce an element of personal bias. Other possible reasons are:

(1) The present statistics are lacking in precision, as already noted. For example, if in a particular area the published record shows that campers are a more serious problem than smokers, and this report indicates that the reverse is true for the same area, the discrepancy may be due to entering berry-pickers as campers in the official classification, whereas the present study indicates that the majority of berry-pickers' fires are started from smoking materials.

(2) To avoid the reporting of an unduly large number of 'unknown' 
fires, the practice in many districts is to assign fires of a doubtful origin to some reasonable cause, such as smokers. This practice may distort the official record very considerably, whereas the questionnaire is free from this kind of bias.

(3) Inasmuch as replies to the questionnaire were not received from every district in all regions, it is realized that the sampling may not be strictly representative, and that bias will appear in the total for that region even though the results are correct for the area from which the reports were actually received.

(4) The results of the questionnaire are intended to be indicative of present conditions, while statistics are often expressed as an average over a period of years and for this reason may not be truly representative of present trends.

The analysis of the replies was made on a basis of political boundaries and the data were grouped chiefly by provinces and related groups of provinces. From the administrative standpoint this grouping is the most convenient one. For special purposes, it might be more useful to group the reports according to some other system, such as the proximity of the areas to settlement, their recreational use, or forest region, but for general purposes the present method was considered desirable.

In summarizing the replies, the answers to the various questions were weighted on the basis of points, five being allotted for a first choice, four for a second choice, and so on, with the fifth choice being given a weight of one. For the replies in which numerous choices were given, those in excess of five were excluded from the compilation. In the case of the question dealing with prevention methods, only the first three choices were taken into consideration, and these were weighted on a three, two, one basis. However, for this question all classes of people were included, even if more classes were listed than were given for Question 2. All replies relating to the specific causes of forest fires were taken into consideration, and each was given an equal weight. The relative importance of each of the general causes was calculated on a percentage basis, taking weights into account. The relative importance of the specific causes for each of the agencies responsible for fire was also expressed as a percentage.

In determining the comparative effectiveness of the various fire prevention methods for the different groups, weights were taken into account, greater weight being given to those methods which were reported as being most effective for the major causes of fires, and lesser weight being given to methods favoured for the minor causes. No differentiation was made between the replies, each being given equal weight irrespective of the rank or grade of the person completing it. In those instances where the replies failed to follow the questions exactly, the most probable correct classification was used if any clues were given in the remarks. Where this was impossible, owing to lack of details, the incorrectly completed data were not used. 
Although the study was concerned primarily with the collection of the opinions of experienced forest protection officers as to the firestarting agencies to which attention should be particularly directed, and with summarizing their suggestions in regard to the best means of approaching the various classes of people responsible for fires, it is hoped that this report may, in addition, serve to emphasize the need for adopting a more complete basis of classifying fire causes, so that in future such analyses may be based on recorded statistics rather than on opinion.

\section{Summary of Results for CANADA}

From the summary of results shown below, it may be seen that, on the average, local citizens cause more fires than visitors or tourists in over four-fifths of the districts from which replies were received. Although Indians seem to be a very minor cause of fires from Ontario eastward, they constitute a more serious problem in Western and Northwestern Canada. On the average, for all regions under consideration, they cause more fires than do whites in about 14 per cent of the districts, and in these districts the average Indian population is 59 per cent of the total.

Two-thirds of the responsibility for fires is placed on settlers, fisherment, road travellers, and berry-pickers, in that order. (See Table 1). Trappers are rated slightly higher than hunters or forest workers. In Eastern Canada, fishermen constitute the greatest problem, whereas in Western Canada settlers are the most important single cause. Camp-fires are considered more serious than smoking materials, with slash or landclearing fires third. It would appear that industrial equipment and power machinery are of relatively minor importance.

With regard to settlers' fires, (Table 2), established farmers cause more trouble than settlers on unimproved land. However, it must be borne in mind that the established farmers are far more numerous than settlers on unimproved land. Squatters and ranchers do not in the main present a serious problem. The principal reasons for settlers' fires are clearing new land and burning hay meadows.

The main single reason for setting incendiary fires is to obtain work (Table 3). Fires set for spite against neighbours are twice as important as those set for the purpose of forcing the opening of land for settlement or to obtain cutting rights. Fires set 'for the love of it' - that is, by 'firebugs'-ranks lowest on the incendiary list.

As a means of fire prevention legisaltive controls, such as permits for forest travel or slash burning, are rated more effective on the average than any of the educational methods. (See Table 4). For most causes, considerable prominence is given to the personal approach (talks to individuals and groups), while radio, posters, and road signs rate higher than schools or movies. Newspapers and booklets are thought to be more effective than magazines. Road signs are emphasized for tourists. 
SUMMARY OF REPLIES FOR CANADA

(a) Class of people responsible for most fires:

Local citizens 84 per cent

Visitors or tourists 16 per cent

(b) Racial origin of those who cause the most fires:

White 86 per cent Indian 14 per cent

(c) Percentage of the population that is Indian:

Average Indian population 12.5 per cent Highest percentage Indian population for any district .100 per cent

In those districts in which Indians were reported to have started more fires than white people the average Indian population was 59 per cent of the total.

Table No. 1

\section{Relative Importance of Causes of Fires}

\begin{tabular}{|c|c|c|c|c|c|c|}
\hline & & & $s p$ & ecific Can & & \\
\hline & & & & Slash & Engines & \\
\hline Relative & General & Camp- & & or Land- & or & \\
\hline Importance & Cause & Fires & Smoking & $\begin{array}{l}\text { Clearing } \\
\text { Relative }\end{array}$ & $\begin{array}{l}\text { Machinery } \\
\text { mportance }\end{array}$ & Total \\
\hline 19 & Settlers & 2 & 22 & 75 & 1 & 100 \\
\hline 18 & Fishermen & 77 & 23 & & & 100 \\
\hline 16 & Road Travellers .. & 30 & 66 & 1 & 3 & 100 \\
\hline 14 & Berry-pickers & 44 & 55 & 1 & & 100 \\
\hline 9 & Trappers ............. & 82 & 15 & 3 & & 100 \\
\hline 8 & Hunters ............... & 67 & 33 & & & 100 \\
\hline 6 & Forest Workers .... & 43 & 36 & 18 & 3 & 100 \\
\hline 4 & Water Travellers .. & 90 & 10 & & & 100 \\
\hline 3 & Road Workers .... & 23 & 18 & 47 & 12 & 100 \\
\hline 2 & Prospectors ......... & 70 & 21 & 9 & & 100 \\
\hline 1 & ….......... & 60 & 8 & 12 & 20 & 100 \\
\hline 100 & Total & 46 & 32 & 20 & 2 & 100 \\
\hline
\end{tabular}


TABLE No. 2

Relative Importance of Reasons for Settlers' Fires

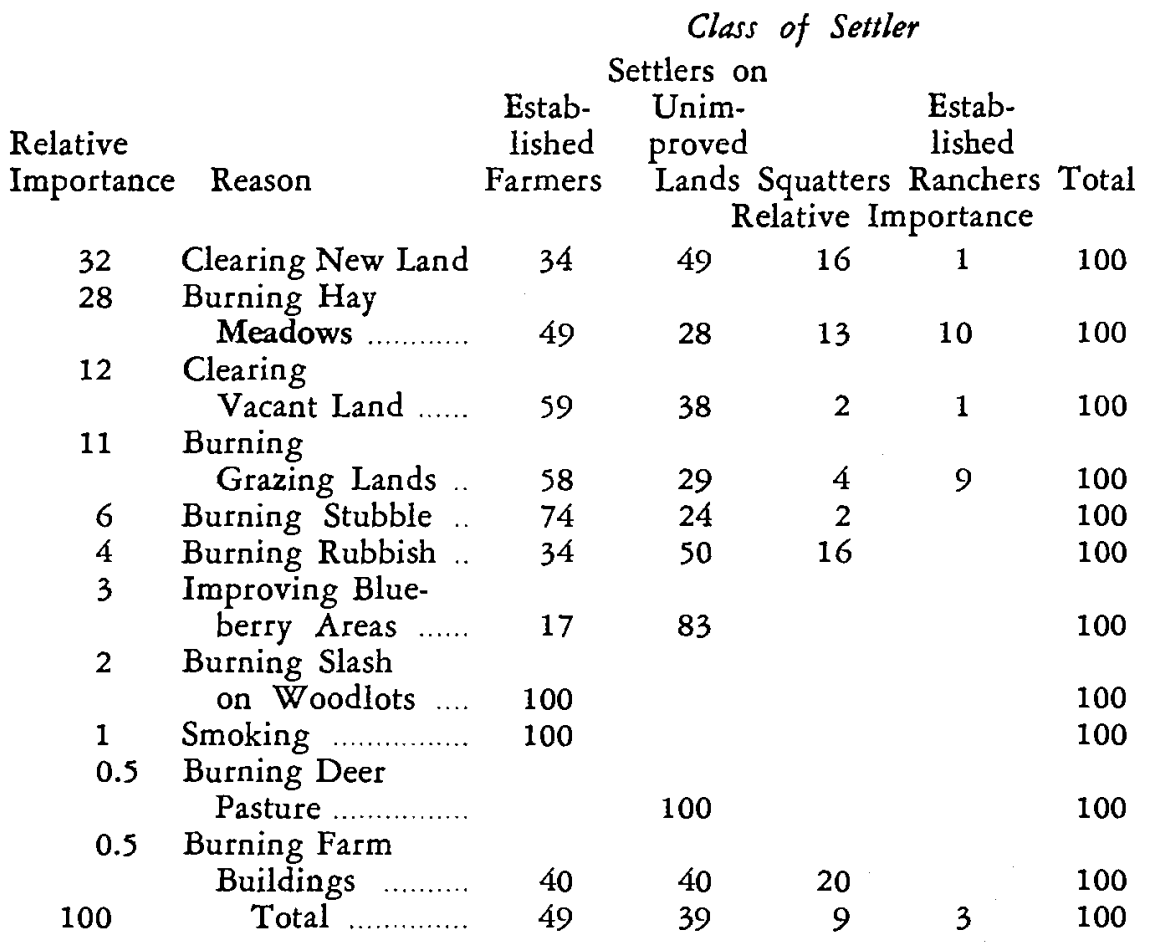

TABIE No. 3

Relative Importance of Reasons for Incendiary Fires

Relative

Importance Reason.

30 To Obtain Work

24 Spite Against Neighbours

12 To Force Opening of Land for Settlement

12 To Obtain Cutting Rights

11 Spite Against Government

6 Spite Against Operators

5 Fire-bugs

100 Total 
TABLE No. 4

Relative Importance of Fire Prevention Methods

(a) For Settlers

\begin{tabular}{cl}
\hline $\begin{array}{l}\text { Relative } \\
\text { Importance }\end{array}$ & \multicolumn{1}{c}{ Method } \\
\hline 30 & Slash-burning Permits \\
11 & Radio \\
10 & Schools \\
9 & Talks to Individuals \\
9 & Movies \\
6 & Road Signs \\
6 & Talks at Meetings \\
5 & Churches and Clergy \\
4 & Posters \\
3 & Booklets \\
3 & Newspapers \\
2 & Camp or Travel Permits \\
1 & Prosecutions \\
1 & Air Patrols \\
& \\
& \\
\hline 100 & Total \\
\hline
\end{tabular}

(c) For Road Travellers

\begin{tabular}{cl}
\hline $\begin{array}{l}\text { Relative } \\
\text { Importance }\end{array}$ & \multicolumn{1}{c}{ Method } \\
\hline 23 & Road Signs \\
16 & Radio \\
14 & Posters \\
12 & Camp or Travel Permits \\
6 & Schools \\
6 & Newspapers \\
5 & Smoking Restrictions \\
5 & Movies \\
5 & Talks to Individuals \\
3 & Prosecutions \\
2 & Booklets \\
1 & Talks at Meetings \\
1 & Magazines \\
1 & Churches and Clergy \\
\hline 100 & Total \\
\hline
\end{tabular}

(b) For Fishermen

\begin{aligned} & \hline \multicolumn{1}{l}{$\begin{array}{l}\text { Relative } \\ \text { Importance }\end{array}$} \multicolumn{1}{c}{ Method } \\ & \hline 22 Camp or Travel Permits \\ & 17 Posters \\ & 16 Radio \\ & 7 Talks to Individuals \\ & 6 Road Signs \\ & 6 Talks at Meetings \\ & 6 Movies \\ & 4 Schools \\ & 3 Booklets \\ & 3 Newspapers \\ & 2 Smoking Restrictions \\ & 2 Magazines \\ & 2 Prosecutions \\ & 2 Churches and Clergy \\ & 1 Notices on Trapping \\ & 1 and Hunting Licences \\ & 1 Slash-burning Permits \\ & \hline 100 Total \\ & \hline\end{aligned}

(d) For Berry-pickers

\begin{aligned} & \hline $\begin{array}{l}\text { Relative } \\ \text { Importance }\end{array} \multicolumn{1}{c}{$ Method } \\ & \hline 21 Camp or Travel Permits \\ & 16 Posters \\ & 13 Schools \\ & 11 Radio \\ & 8 Road Signs \\ & 6 Talks to Individuals \\ & 6 Smoking Restrictions \\ & 6 Churches and Clergy \\ & 4 Movies \\ & 3 Prosecutions \\ & 2 Talks at Meetings \\ & 2 Newspapers \\ & 1 Booklets \\ & 1 Slash-burning Permits \\ & \hline 100 Total \\ & \hline\end{aligned}


TABLE No. 4-Continued

Relative Importance of Fire Prevention Methods (Cont'd)

(e) For Trappers

\begin{aligned} & \hline Relative \multicolumn{1}{c}{ Method } \\ & \hline Importance \multicolumn{1}{c}{ Camp or Travel Permits } \\ & \hline 21 Posters \\ & 13 Talks to Individuals \\ & 11 Radio \\ & 9 Talks at Meetings \\ & 6 Schools \\ & 5 Movies \\ & 4 Booklets \\ & 3 Road Signs \\ & 3 Magazines \\ & 3 Churches and Clergy \\ & 2 Newspapers \\ & 1 Slash-burning Permits \\ & 1 Prosecutions \\ & 1 Air Patrols \\ & 1 Smoking Restrictions \\ & \hline 100 Total \\ & \hline\end{aligned}

(g) For Forest Workers

\begin{aligned} & \hline $\begin{array}{l}\text { Relative } \\ \text { Importance }\end{array} \multicolumn{1}{c}{$ Method } \\ & \hline 21 Smoking Restrictions \\ & 14 Talks to Individuals \\ & 13 Road Signs \\ & 12 Posters \\ & 9 Radio \\ & 8 Talks at Meetings \\ & 6 Slash-burning Permits \\ & 5 Movies \\ & 4 Camp or Travel Permits \\ & 4 Booklets \\ & 2 Schools \\ & 1 Newspapers \\ & 1 Magazines \\ & \\ & \hline 100 Total \\ & \hline\end{aligned}

(f) For Hunters

\begin{tabular}{cl}
\hline $\begin{array}{l}\text { Relative } \\
\text { Importance }\end{array}$ & \multicolumn{1}{c}{ Method } \\
\hline 18 & Camp or Travel Permits \\
17 & Posters \\
12 & Radio \\
10 & Smoking Restrictions \\
7 & Road Signs \\
6 & Movies \\
5 & Schools \\
5 & Talks at Meetings \\
5 & Talks to Individuals \\
4 & Booklets \\
3 & Newspapers \\
3 & Magazines \\
3 & Churches and Clergy \\
1 & Slash-burning Permits \\
1 & Notices on Trapping \\
& and Hunting Licences \\
\hline 100 & Total \\
\hline
\end{tabular}

(h) For Water Travellers

\begin{aligned} & \hline $\begin{array}{l}\text { Relative } \\ \text { Importance }\end{array} \multicolumn{1}{c}{$ Method } \\ & \hline 22 Posters \\ & 18 Camp or Travel Permits \\ & 13 Radio \\ & 10 Talks to Individuals \\ & 7 Movies \\ & 6 Road Signs \\ & 5 Booklets \\ & 5 Newspapers \\ & 5 Schools \\ & 2 Magazines \\ & 2 Talks at Meetings \\ & 2 Smoking Restrictions \\ & 1 Churches and Clergy \\ & 1 Air Patrols \\ & 1 Slash-burning Permits \\ & \hline 100 Total \\ & \hline\end{aligned}


FIRE-DOYLE

TABLE No. 4-Continued

Relative Importance of Fire Prevention Methods (Cont'd)

(i) For Road Workers

\begin{tabular}{cl}
\hline $\begin{array}{l}\text { Relative } \\
\text { Importance }\end{array}$ & \multicolumn{1}{c}{ Method } \\
\hline 21 & Slash-burning Permits \\
19 & Smoking Restrictions \\
17 & Talks to Individuals \\
11 & Posters \\
10 & Road Signs \\
7 & Radio \\
5 & Camp or Travel Permits \\
3 & Talks at Meetings \\
2 & Booklets \\
2 & Movies \\
2 & Schools \\
1 & Newspapers \\
& \\
& \\
& \\
\hline 100 & Total \\
\hline
\end{tabular}

(j) For Prospectors

\begin{tabular}{cl}
\hline $\begin{array}{l}\text { Relative } \\
\text { Importance }\end{array}$ & \multicolumn{1}{c}{ Method } \\
\hline 20 & Camp or Travel Permits \\
12 & Radio \\
12 & Talks to Individuals \\
12 & Smoking Restrictions \\
10 & Posters \\
8 & Booklets \\
4 & Newspapers \\
4 & Magazines \\
4 & Schools \\
3 & Road Signs \\
3 & Talks at Meetings \\
2 & Movies \\
2 & Slash-burning Permits \\
2 & Air Patrols \\
1 & Churches and Clergy \\
1 & Prosecutions \\
\hline 100 & Total \\
\hline
\end{tabular}

(k) For Miners

\begin{aligned} & \hline $\begin{array}{l}\text { Relative } \\ \text { Importance }\end{array} \multicolumn{1}{c}{$ Method } \\ & \hline 18 Radio \\ & 14 Posters \\ & 13 Talks to Individuals \\ & 10 Camp or Travel Permits \\ & 9 Road Signs \\ & 8 Movies \\ & 8 Newspapers \\ & 5 Booklets \\ & 5 Schools \\ & 5 Talks at Meetings \\ & 2 Slash-burning Permits \\ & 2 Smoking Restrictions \\ & 1 Churches and Clergy \\ & \hline 100 Total \\ & \hline\end{aligned}




\section{SUMMARY OF RESUlTS BY RegIONS}

(a) The Maritime Provinces and Newfoundland

In all districts of the Maritime Provinces and Newfoundland, local citizens were reported to have caused more fires than visitors and tourists while Indians appear to be a very minor cause.

Over four-fifths of the responsibility for fires is placed on fishermen, road travellers, settlers, and berry-pickers, in that order. Smoking is considered to be a more serious problem than camp-fires, with slash or landclearing fires third. Industrial equipment and power machinery are considered to be a relatively unimportant cause.

Among settlers, established farmers are a more serious problem than are newcomers, and account for 70 per cent of the 'importance rating' in this group. Clearing new land and burning hay meadows are the two main reasons for settlers' fires, and these are followed by the burning of grazing land and the clearing of vacant land in that order.

The most important reason for incendiarism is to obtain work, with spite against neighbors a close second. More fires are set for spite against the government than for spite against operators. About ten per cent of the incendiary fire problem is associated with fires set by 'fire-bugs'.

In general, legislative controls are rated as being more effective for fire prevention than are any of the individual educational methods. However, educational methods collectively rate higher in a number of cases than do legislative controls. Schools and radio are placed well up for most classes, and posters usually rate higher than road signs. The personal approach is given considerable prominence, especially for fishermen and settlers. Camp-fire or travel permits are emphasized for fishermen and berry-pickers, as are smoking restrictions for forest and road workers.

\section{(b) Quebec and Ontario}

Information with regard to Quebec is based on replies received from two of the forest protective associations in that province and is therefore unlikely to be truly representative of the general conditions within the Province as a whole. For this reason the reader is cautioned against assuming that the data are representative of general conditions within the entire region.

Indians are a minor cause of fires in all the districts of Ontario and Quebec for which replies were received, while local citizens are a greater problem than visitors or tourists in about three-quarters of the districts.

Nearly three-quarters of the responsibility for fires is placed on fishermen, settlers, berry-pickers, and road travellers, in that order. Smoking is considered to be a more important specific cause than camp-fires, with slash and land-clearing fires third. Industrial machinery and power equipment are not given prominence in any district.

Among settlers, established farmers cause more concern than those who are newly established on unimproved lands. Squatters are relatively un- 
important. However, clearing new land is the main single reason for settlers' fires.

The most important reason for incendiary fires is to obtain work. Forcing the opening of land for settlement is next, and these two reasons have a combined importance rating of 77 per cent, with respect to all fires set with intent to destroy property. It would appear that comparatively few fires are caused by 'fire-bugs'.

Like the Maritimes and Newfoundland, legislative controls are generally considered to be much more effective than are educational methods, when the latter are considered individually. Posters and radio are placed well up for most causes, usually higher than road signs, movies, and schools. Newspapers are a little higher than booklets or magazines. The personal approach is given considerable prominence, particularly for settlers and forest workers, while road signs are emphasized for tourists.

\section{(c) The Prairie Provinces}

The summary of the results indicated that for the Prairie Provinces local citizens are a much greater problem than visitors or tourists as 87 per cent of the responsibility for fires is placed directly on them. Indians are the cause of most fires in about one-quarter of all districts, and it is interesting to note that in the districts where Indians cause more fires than white people, the average Indian population is 64 per cent of the total.

Approximately one-quarter of the blame for fires in the three Prairie Provinces is placed on settlers. Next come trappers, hunters, berry-pickers, and road travellers in that order. Camp-fires are rated as more than twice as important as smoking materials, with slash or land-clearing fires third.

Clearing new land is the main single reason for settlers' fires. This cause, together with the burning of hay meadows and the clearing of vacant land, account for four-fifths of the settlers' fire problem. Settlers on unimproved land are more important than established farmers, with squatters third. Established ranchers cause relatively few fires.

The major reason for incendiary fires is to force the opening of land for settlement. The securing of cutting rights is next, with fires set for the purpose of obtaining work third. The above causes comprise nearly two-thirds of the total rating for incendiary fires.

The replies from this region indicated that the personal approach (talks to individuals and groups) is slightly more effective in reducing forest fires than are legislative controls or any of the other educational methods. Radio and posters receive considerable prominence for most causes, usually more than do movies and road signs, while booklets and newspapers rate higher than magazines. Slash-burning permits are emphasized for settlers.

(d) The National Parks

The fire prevention problem within the National Parks is considerably different from that to be found in most other forested areas in Canada. Because they are used primarily for recreational purposes, it is to be expect- 
ed that the general and specific causes of fires may differ somewhat from those encountered in other areas less frequented by tourists, campers and picknickers. It is not surprising, then, that in the Parks visitors or tourists are rated as a substantially greater fire risk than are local citizens, and that Indians cause more fires than white people in only five per cent of the districts. In this five per cent, however, the average Indian population is only 20 per cent of the total.

Road travellers, fishermen, settlers, and hunters, in that order, constitute nearly three-quarters of the fire problem. More importance is attached to camp-fires than to smoking materials, with slash or land-cleasing fires third. Only a few fires are the direct result of industrial machinery or power equipment.

The two most important reasons for settlers' fires are the burning of hay meadows, and the clearing of niew land. Established farmers are rated twice as important as settlers on unimproved land. It should be borne in mind that settlers' fires do not originate within the Parks, but may spread in from adjacent farming areas; this also applies to fires set by hunters.

The most important reason for incendiary fires is to obtain work. Fires set to obtain cutting rights are next followed by those which are set for spite against the government. 'Fire-bugs' are believed to be responsible for a small percentage of incendiary fires.

For most causes legislative controls (permits and restrictions) are considered to be among the most effective means of reducing the number of forest fires in the National Parks. The personal approach is considered to be the next best method, followed closely by the following three educational methods in this order: posters, road signs, and radio. Movies are placed above schools, while booklets are rated higher than newspapers or magazines. Road signs are emphasized for tourists, as are camp-fire or travel permits for fishermen.

\section{(e) Yukon and Northwest Territories}

In nearly two-thirds of the districts of the Yukon and Northwest Territories, Indians are considered to be the major cause of fires. It is worthy of note that in the districts where Indians cause more fires than white people the average Indian population amounts to 61 per cent of the total, while the average Indian population for all districts (unweighted) is 46.5 per cent of the total inhabitants. Only about one-tenth of the responsibility for man-caused fires is placed on visitors or tourists.

Two-thirds of the blame for all fires is attributed to trappers, hunters, fishermen, and water travellers, in that order, trappers being much the most important. Among the specific causes, the importance rating of campfires is 85 per cent, while smoking and slash or land-clearing fires are considered to be of relatively minor importance. Settlers are the cause of very few fires.

For this region the consensus is that the personal approach is the most effective method of reducing the number of fires, prominence being given to personal contacts and talks at meetings for most causes. Posters are 
next, followed by movies and legislative controls, in that order, and road signs rate higher than booklets or radio.

\section{COMMENTS BY REPORTING OFFICERS}

Many of the reporting officers took advantage of the questionnaire to advance constructive suggestions, some of which are summarized below. It should be noted that many of the practices recommended for adoption in certain districts are already in use in other parts of Canada.

A more rigid enforcement of existing legislative controls, particularly in regard to slash-burning and forest travel permits, was frequently suggested. It was felt in many districts that the personal investigations by rangers of the area to be burned prior to the issuance of slash-burning permits was a most effective method of reducing the fires from this cause. In addition to eliminating many hazardous conditions, the system provides excellent opportunities for the ranger to make valuable personal contacts with individuals, and situations are presented which are conducive to the discussion of fire protection problems. Some felt that the establishment of permanent forest boundaries would be an important step toward decreasing the number of settlers' fires in those areas where the land is in demand and where the practice has been to open burned-over land for settlement. A further recommendation was that all large-scale slash-burning projects be supervised.

The increased use of bulldozers for land clearing is creating a special fire hazard in some areas. Fires in bulldozed material which has been improperly piled are very difficult to extinguish, since they often smoulder for considerable periods of time even in comparatively wet weather. In one district it was reported that most fires caused by settlers resulted from burning debris from bulldozed slash. In this regard another protection officer suggested that regulations be drawn up to ensure that the slash is bulldozed so that it does not become a serious fire hazard. The opinion was advanced that to date the importance of this particular hazard has been generally overlooked by fire prevention officials.

One officer called for the issuance of camp-fire and travel permits to all those who frequent the forest, including forest workers, those for the latter being issued for the duration of the operation on which they are engaged. An experiment in one district whereby leaflets were distributed to motorists at a road block was reported to have worked well. It was suggested that more forest wardens be put on duty (presumably patrol duty) during the dangerous fire periods, and that every effort should be made to get convictions where there is reason to believe that fires have been started maliciously or by people indifferent to the fire laws.

Some officers felt that there were many fishermen and tourists who did not know how to build safe camp-fires, and that it would be wise if more prepared camping places were provided for forest travellers. One observer noted that the fishermen most careful with fire were those who belonged to fish and game clubs, while another reported that most water travellers were campers of school age. 
Many fires result from the burning of grass on marshes by trappers for the purpose of revealing the location of muskrat houses. Others spread from fires set in certain areas to facilitate the finding of seneca root, and from the burning-off by prospectors of the overburden on rock to uncover mineral veins. It was thought that it would be helpful if prominent fire protection notices were on all hunting, trapping, and fishing licences and on camp fire and travel permits.

It was suggested that warnings, broadcast by radio during periods of high danger, would be well worth while. These warnings should preferably be included as part of the regular news broadcasts. It was reported from one district that travellers were greatly impressed by an experiment whereby a fire patrol plane followed the highway and warned motorists, over a public address system located in the aircraft, of existing conditions of high fire danger. Another observer reported the successful use of a public address system in berry-picking areas, whereby warnings of hazardous fire conditions were given to the berry-pickers, with beneficial results.

Several protection officers felt that fire prevention posters should be prepared in the language of the majority of the inhabitants of the district. It was reported that in one area posters printed in the Cree tongue were distributed with excellent results.

Some thought that it would be wise if the clergy would draw periods of high forest fire danger to the attention of their congregations, and that this could be done conveniently by the clergyman when he is making his announcements for the week. However, the opinion was noted that on the average the fire laws are now being more carefully observed than they were a few years ago, and that this improvment is due primarily to increased education in forest fire prevention. 